\title{
Stocking rate, precipitation, and herbage production on sand sagebrush-grassland
}

\author{
ROBERT L. GILLEN AND PHILLIP L. SIMS
}

Authors are Rangeland Scientists, Southern Plains Range Research Station, USDA-ARS, 2000 18th Street, Woodward, Okla. 73801.

\author{
Abstract
}

Knowledge of the relationship between stocking rate or grazing intensity and plant production is fundamental to the sustainable management of rangelands. The general management paradigm is that plant production declines as stocking rate increases. Our objective was to determine the impact of stocking rate on herbaceous production of a sand sagebrush (Artemisia filifolia Torr.)grassland. Stocking rates averaging 43,57 , and 85 animal-unitdays $\mathrm{ha}^{-1}$ (AUD ha ${ }^{-1}$ ) for year-round grazing were applied from 1941 to 1961 . Herbaceous plant production was determined by sampling standing crop in temporary exclosures at the end of the growing season from 1958 to 1961 , the last 4 years of the grazing study. Total herbaceous production averaged over stocking rates and years was $1,490 \mathrm{~kg} \mathrm{ha}^{-1}$. Grasses contributed $89 \%$ of the total while forbs contributed $11 \%$. Total production averaged 1,540 , 1,470 , and $1,450 \mathrm{~kg} \mathrm{ha}^{-1}$ for stocking rates of 43,57 , and 85 AUD $h^{-1} \mathbf{y}^{-1}$, respectively. There were no differences among stocking rates for total production or for the production of any individual grass species $(\mathrm{P}>\mathbf{0 . 0 5}$ ). Forb production was also not affected by stocking rate, averaging 200,140 , and $120 \mathrm{~kg} \mathrm{ha}^{-1}$ for stocking rates of 43,57 , and $85 \mathrm{AUD} \mathrm{ha}^{-1} \mathrm{y}^{-1}(\mathrm{P}>0.05)$. Differences in production among years were much greater than differences among stocking rates for all vegetation components. Little bluestem [Schizachyrium scoparium (Michx.) Nash] and sand lovegrass [Eragrostis trichodes (Nutt.) Wood] showed the greatest responses to favorable precipitation. Herbaceous production of this sand sagebrush-grassland was little affected by 20 years of differential stocking rates.

Key Words: grazing intensity, mixed prairie, biomass, composition

Knowledge of the relationships between stocking rate or grazing intensity and plant production is fundamental to the sustainable management of rangelands. Stocking rate is generally con-

The authors acknowledge the contributions of D. A. Savage (deceased), E. H. Mcllvain (retired), M. C. Shoop (retired), the Southern Plains Experimental Range technicians, and Sherry Dewald and other personnel at the Southern Plains Range Research Station for their assistance in this work. The cooperation and contribution to the research of the Pecos Anderson Family, owners, Canadian River Cattle Co., Canadian, Tex., is appreciated.

All programs and services of the U. S. Department of Agriculture are offered on a nondiscriminatory basis without regard to race, color, national origin, religion, sex, age, marital status or handicap.

Names are necessary to report factually on available data, however, the USDA neither guarantees nor warrants the standard of the product, and the use of the name by USDA implies no approval of the product to the exclusion of others that may also be suitable.

Manuscript accepted 24 Jun. 03.

\section{Resumen}

El conocimiento de la relación entre la carga animal o la intensidad del apacentamiento con la producción de las plantas es fundamental para un manejo sustentable de los pastizales. El paradigma general de manejo es que la producción de la planta disminuye al incrementar la carga animal. Nuestro objetivo fue determinar el impacto de la carga animal en la producción herbácea de un una comunidad de "Sand sagebrush" (Artemisia filifolia Torr.)- pastizal. De 1941 a 1961 se aplicaron cargas animal que promediaron 43, 57, y 85 unidades- animal- día ha ${ }^{-1}$ (AUD ha-1) bajo un sistema de apacentamiento continuo. La producción herbácea se determinó muestreando la biomasa en pie dentro de exclusiones temporales al final de la estación de crecimiento de los últimos 4 años del estudio de apacentamiento (de 1958 a 1961). La producción total herbácea promedio de todas las cargas animal fue de $1,490 \mathrm{~kg} \mathrm{ha}^{-1}$. Los zacates contribuyeron con el $89 \%$ del total mientras que las hierbas aportaron el $11 \%$. La producción total promedio $1,540,1,470$ y $1,450 \mathrm{~kg} \mathrm{ha}^{-1}$ para las cargas de 43, 57, y $85 \mathrm{AUD} \mathrm{ha}^{-1}$ año $^{-1}$ respectivamente. No hubo diferencia entre las cargas animal respecto a la producción total ni para la producción de las especies individuales de zacates $(P$ > 0.05). La producción de hierbas tampoco fue afectada por la carga animal, promediando 200,140, y $120 \mathrm{~kg} \mathrm{ha}^{-1}$ para las cargas animal de 43, 57, y 85 AUD ha- año $^{-1}(P>0.05)$. Las diferencias en producción entre años fueron mucho mayores que las diferencias entre cargas animal, esto fue igual para todos los componentes de la vegetación. El "Little bluestem" [Schizachyrium scoparium (Michx.) Nash] y "Sand lovegrass" [Eragrostis trichodes (Nutt.) Wood] mostraron la mayor respuesta a la precipitación favorable. La producción de esta comunidad de "Sand sagebrush" (Artemisia filifolia Torr.)- pastizal fue poco afectada por los 20 años cargas animales diferenciales a las que estuvo sometida.

sidered the primary factor in grazing management of Great Plains grasslands over periods of 10 or more years. The general management paradigm is that plant production declines as stocking rate increases (Holechek et al. 1995).

A global analysis of grazing intensity and plant production found that as grazing intensity increases, aboveground net primary productivity generally decreases (Milchunas and Lauenroth 1993). However, the relationship was weak and dependent on overall site productivity and evolutionary history of grazing. Previous studies on sandy rangelands in the western Great Plains reported a decrease of 20 to $25 \%$ in annual herbaceous production over time as stocking rates were doubled (Burzlaff and Harris 1969, Sims et al. 1976). Responses of individual species 
were variable with little change in 1 study (Burzlaff and Harris 1969) and clear directional changes for individual species in the second study (Sims et al. 1976).

A 20-year research project was initiated in 1941 at the Southern Plains Experimental Range to determine the impact of stocking rate on sand sagebrush-grassland of the Southern Great Plains. This paper reports the response of herbaceous production to different stocking rates as measured over the final 4 years of this long-term study. Our hypothesis was that herbaceous production would decline as stocking rate increased.

\section{Materials and Methods}

The Southern Plains Experimental Range (SPER) is located in northwestern Oklahoma $27 \mathrm{~km}$ northwest of Woodward $\left(99^{\circ} 23^{\prime} \mathrm{W}, 36^{\circ} 27^{\prime} \mathrm{N}\right.$, elevation $610-640$ m). The long-term (1940 to 2000) average precipitation is $576 \mathrm{~mm}$ with $77 \%$ of this amount occurring during the April-toOctober growing season.

The landscape is gently rolling, stabilized sand dunes frequently interspersed with areas of heavier-textured soils with no well-defined drainage patterns. Eda loamy sands (formerly designated as Pratt; mixed, thermic Lamellic Ustipsamments) are on lower slopes and interdune areas, and Tivoli fine sands (mixed, thermic Typic Ustipsamments) occur on upper slopes. The vegetation is dominated by sand sagebrush (Artemisia filifolia Torr.), which had an average canopy cover of $38 \%$ during the period of study. The herbaceous understory is a mixture of tall, mid, and short warm-season grasses, and forbs. Classified as sandsage-bluestem (Artemisia-Andropogon) prairie by Küchler $(1964,1975)$, this vegetation type dominates the landscape along the major rivers that flow diagonally across the Southern Plains (Berg 1994).

\section{Experimental Treatments}

A range of grazing intensity treatments was selected to determine the sustainable level of long-term forage utilization. Three stocking rates with continuous grazing were initiated in 1941 with 2 replications. Treatment pastures ranged in size from 43 to 86 ha. For the 1941 to 1951 period, the 3 stocking rate treatments were 41,53 , and 82 animal-unit-days (AUD) ha ${ }^{-1} \mathrm{y}^{-1}$ (Sims and Gillen 1999). Each steer was 0.67 animal unit, based on average initial weight of $213 \pm 11 \mathrm{~kg}$ (SE) and an average gain of $168 \mathrm{~kg} \mathrm{hd}^{-1}$ for the 320-day grazing season (13 Nov. to $29 \mathrm{Sep}$.). During the cow-calf phase of the study, from 1952 to 1961 , the stocking rates were increased slightly to 45,60 , and 87 AUD $\mathrm{ha}^{-1} \mathrm{y}^{-1}$, and cattle grazed the pastures year-round. This resulted in average stocking rates over the entire period of study of 43,57 , and 85 AUD ha ${ }^{-1} \mathrm{y}^{-1}$. The middle stocking rate was set so that approximately $2 / 3$ of the annual herbage production would be utilized by the end of the dormant season, about April 20 (Shoop and Mcllvain 1971). This resulted in a $25-\mathrm{mm}$ stubble on the shortgrasses and a 75- to $100-\mathrm{mm}$ stubble on the tall grasses by late winter.

\section{Herbage measurements}

Annual production was estimated by sampling herbage standing crop in exclosures in all treatment pastures at the end of the growing season from 1958 to 1961 , the last 4 years of the grazing study. The average sample date was 5 November with a range from early October to late November.

Standing crop of herbage was determined using the micro-unit forage inventory method described by Shoop and Mcllvain (1963), a variation of the weightestimate method (Pechanec and Pickford 1937). All measurements were estimates. Shoop and Mcllvain (1963) reported that the method tended to underestimate standing crop by about $8 \%$ compared to clipping. Maintenance of accuracy was addressed by using experienced field personnel who trained before sampling periods and checked their estimates by clipping about every tenth plot.

Four quadrats, $0.29 \times 0.61 \mathrm{~m}$, were estimated within portable barbed-wire exclosures measuring $3.7 \times 3.7 \mathrm{~m}$. Twenty exclosures were placed in each pasture and were moved to new locations each year. Standing crop of current year's herbage was recorded separately for the most prominent grasses and for forbs as a group. Grasses estimated separately included sand bluestem [Andropogon hallii Hack.], little bluestem [Schizachyrium scoparium (Michx.) Nash], sand lovegrass [Eragrostis trichodes (Nutt.) Wood], sand paspalum [Paspalum setaceum Michx.], fall witchgrass [Digitaria cognata var. cognata (J.A. Schultes) Pilger], sand dropseed [Sporobolus cryptandrus (Torr.) Gray], and blue grama [Bouteloua gracilis (Willd. ex Kunth) Lag. ex Griffiths]. All other grasses were lumped into a miscellaneous grass component.

\section{Data Analyses}

Herbage production data were analyzed as a completely randomized design using analysis-of-variance with repeated measures. Stocking rate was the main plot factor and year was the repeated factor. Separate analyses were performed for all individual grasses that contributed more than $5 \%$ of annual herbaceous production, total grasses, forbs, and total herbaceous production. PROC MIXED (Version 8; SAS Institute Inc., 1999) was used for all analyses with the covariance structure specified as first-order autoregressive. If treatment effects were significant $(\mathrm{P}<$ 0.05 ), all pair-wise comparisons were made within a given treatment. The Tukey procedure was used to adjust $\mathrm{P}$-values for these families of comparisons.

\section{Results}

\section{Precipitation}

Precipitation patterns can be grouped into 3 distinct periods over the course of the study (Fig. 1). Precipitation from 1941 to 1950 averaged $659 \mathrm{~mm}$, which is $14 \%$ above the long-term average of $576 \mathrm{~mm}$. A severe drought occurred from 1951 until 1956. During this period, annual precipitation averaged $393 \mathrm{~mm}$, about $64 \%$ of the long-term average, winter precipitation was consistently below the norm, and summer rainfall exceeded the average only in 1955. Precipitation was again high, averaging $765 \mathrm{~mm}$, in the period 1957 to 1961. Summer and annual precipitation was above average every year during this period. Our data were collected during a period of favorable precipitation when the vegetation was recovering from a major drought.

\section{Annual Production}

Total annual production from herbaceous species was $1,490 \mathrm{~kg} \mathrm{ha}^{-1}$ when averaged over stocking rates and years. Grasses comprised $89 \%$ of the herbaceous standing crop and $11 \%$ was contributed by forbs. Six grasses individually contributed between 10 and $15 \%$ of total production, the 3 most productive were blue grama, sand lovegrass, and sand paspalum. Common forbs included annual buckwheat (Eriogonum annuum Nutt.), horseweed (Conyza canadensis (L.) Cronq.), and whitemouth dayflower (Commelina erecta $\mathrm{L}$.).

Stocking Rate Effects. After 17 to 20 years of treatment, stocking rate had little impact on herbaceous production. There were no differences among stocking rates 


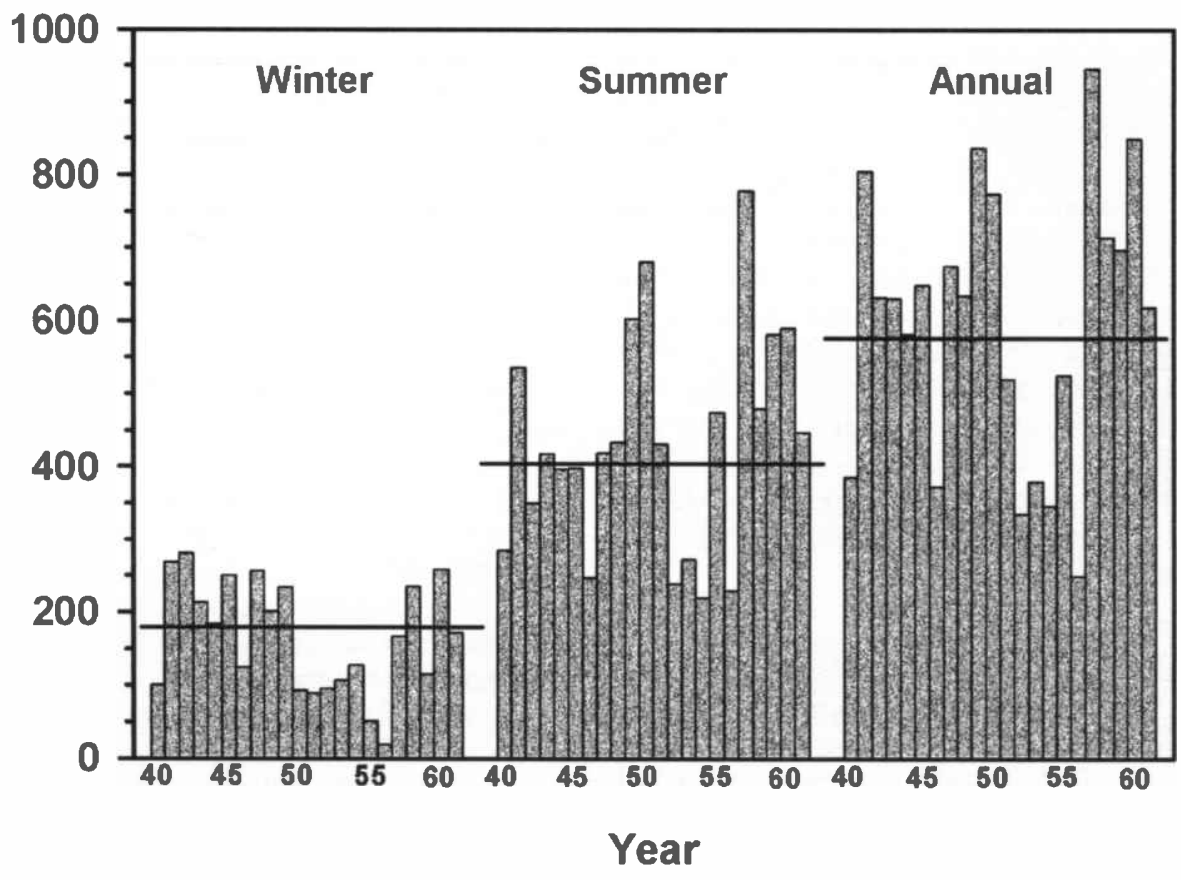

Fig. 1. Winter, summer, and annual precipitation $(\mathrm{mm})$ from 1940 to 1961 at the Southern Plains Experimental Range, Fort Supply, Okla. Horizontal lines indicate long-term averages (1940-2000).

for total production or for the production of any component (Table $1, \mathrm{P}>0.05$ ). This lack of impact was consistent over years as the stocking rate-by-year interaction was not significant for any component $(\mathrm{P}>0.05)$.

Relative composition was not impacted by stocking rate with 1 exception (Table 1). Sand dropseed was affected by the interaction of stocking rate and year (Table $2, P=0.02$ ). The relative composition of sand dropseed was similar among stocking rates for the first 3 years but increased at the highest stocking rate in 1961 . blue grama (Table 3 ). Relative composition also varied over years for most components; the exceptions were sand bluestem and sand paspalum (Table 3 ). Little bluestem and sand lovegrass had the largest directional changes over the study period. Production increased by factors of 6 for little bluestem and 10 for sand lovegrass between 1958 and 1961. Relative composition also showed large positive responses over time for these 2 grasses. Production of sand dropseed and blue grama showed little response over time but relative composition of these 2 grasses decreased. Forb production fluctuated over years with no discernable trend.

\section{Discussion}

Herbaceous production of this sand sagebrush-grassland was little affected by 20 years of differential stocking rates. Previous studies on sandy rangeland in the western Great Plains reported reductions in herbaceous production as stocking rate increased. Over the last 3 years of a 10year study in Nebraska, Burzlaff and Harris (1969) reported herbaceous production declined by $21 \%$ when stocking rate was doubled. Similarly, over the final 4 years of a 9-year study in Colorado, Sims et al. (1976) found a reduction of $24 \%$ in herbaceous production as stocking rate doubled. On average, herbaceous production declined in these studies by $11.8 \mathrm{~kg}$ $\mathrm{ha}^{-1}$ for each increase of 1 AUD ha ${ }^{-1}$ in stocking rate. In the current study this ratio was 0.2 and the reduction in herbaceous production was not significant.

Table 2. Relative composition of sand dropseed as affected by the interaction of stocking rate and year.

Table 1. Herbaceous production and relative composition as affected by stocking rate, 1958-1961.

\begin{tabular}{|c|c|c|c|c|c|c|c|c|}
\hline \multirow[b]{3}{*}{ Vegetation } & \multirow{2}{*}{\multicolumn{4}{|c|}{$\begin{array}{l}\text { Production } \\
\text { Stocking rate } \\
\left(\text { AUD ha }{ }^{-1} y^{-1}\right)\end{array}$}} & \multirow{2}{*}{\multicolumn{4}{|c|}{$\begin{array}{c}\text { Relative composition } \\
\text { Stocking rate } \\
\left(\text { AUD ha }{ }^{-1} \mathrm{y}^{-1} \text { ) }\right.\end{array}$}} \\
\hline & & & & & & & & \\
\hline & 43 & 57 & 85 & SE & 43 & 57 & 85 & SE \\
\hline Component & \multicolumn{4}{|c|}{ - } & \multicolumn{4}{|c|}{ 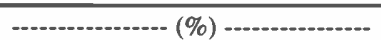 } \\
\hline Sand bluestem & $60^{1}$ & 70 & 50 & 10 & 4 & 4 & 4 & 1 \\
\hline Little bluestem & 180 & 160 & 80 & 25 & 11 & 10 & 6 & 2 \\
\hline Sand lovegrass & 270 & 280 & 130 & 40 & 15 & 18 & 9 & 2 \\
\hline Sand paspalum & 180 & 210 & 190 & 30 & 12 & 15 & 13 & 3 \\
\hline Fall witchgrass & 150 & 200 & 160 & 20 & 10 & 14 & 12 & 2 \\
\hline Sand dropseed & 140 & 130 & 170 & 30 & $10^{2}$ & 9 & 10 & 2 \\
\hline Blue grama & 210 & 90 & 330 & 140 & 14 & 7 & 23 & 7 \\
\hline Other grasses & 160 & 200 & 210 & 15 & 10 & 14 & 15 & 1 \\
\hline Total grasses & 1,340 & 1,330 & 1,330 & 120 & 86 & 90 & 91 & 1 \\
\hline Forbs & 200 & 140 & 120 & 20 & 14 & 10 & 9 & 1 \\
\hline Total herbage & 1,540 & 1,470 & 1,450 & 140 & & & & \\
\hline
\end{tabular}

Main effect of stocking rate is not significant for any component, $P>0.05$.

${ }^{2}$ Significant stocking rate by year interaction, $\mathrm{P}=0.02$. 
Table 3. Herbaceous production and relative composition as affected by year, averaged over stocking rate.

\begin{tabular}{|c|c|c|c|c|c|c|c|c|c|c|}
\hline \multirow{3}{*}{$\begin{array}{l}\text { Vegetation } \\
\text { component }\end{array}$} & \multicolumn{5}{|c|}{ Production } & \multicolumn{5}{|c|}{ Relative composition } \\
\hline & \multicolumn{5}{|c|}{ Year } & \multicolumn{5}{|c|}{ Year } \\
\hline & 1958 & 1959 & 1960 & 1961 & SE & 1958 & 1959 & 1960 & 1961 & SE \\
\hline & \multicolumn{5}{|c|}{ ……- $\left(\mathrm{kg} \mathrm{ha}^{-1}\right)-1$} & \multicolumn{5}{|c|}{ - } \\
\hline Sand bluestem & $50^{b 1}$ & $30^{\mathrm{b}}$ & $50^{\mathrm{b}}$ & $100^{\mathrm{a}}$ & 10 & 4 & 3 & 4 & 5 & 1 \\
\hline Little bluestem & $50^{\mathrm{c}}$ & $90^{b c}$ & $120^{\mathrm{b}}$ & $290^{\mathrm{a}}$ & 25 & $4^{\mathrm{c}}$ & $9^{b}$ & $8^{\mathrm{bc}}$ & $14^{\mathrm{a}}$ & 2 \\
\hline Sand lovegrass & $50^{\mathrm{d}}$ & $120^{\mathrm{c}}$ & $240^{\mathrm{b}}$ & $510^{a}$ & 35 & $3^{\mathrm{c}}$ & $12^{\mathrm{b}}$ & $16^{\mathrm{b}}$ & $24^{a}$ & 2 \\
\hline Sand paspalum & $180^{b}$ & $130^{\mathrm{b}}$ & $150^{\mathrm{b}}$ & $320^{\mathrm{a}}$ & 30 & 14 & 14 & 10 & 16 & 3 \\
\hline Fall witchgrass & $100^{b}$ & $140^{\mathrm{b}}$ & $210^{a}$ & $240^{\mathrm{a}}$ & 20 & $8^{b}$ & $14^{\mathrm{a}}$ & $15^{\mathrm{a}}$ & $11^{\mathrm{ab}}$ & 2 \\
\hline Sand dropseed & $220^{a}$ & $80^{b}$ & $80^{b}$ & $200^{\mathrm{a}}$ & 20 & $16^{2}$ & 8 & 5 & 9 & 1 \\
\hline Blue grama & $260^{a}$ & $230^{\mathrm{a}}$ & $160^{a}$ & $190^{\mathrm{a}}$ & 80 & $17^{\mathrm{ab}}$ & $22^{\mathrm{a}}$ & $11^{\mathrm{b}}$ & $9^{b}$ & 5 \\
\hline Other grasses & $250^{\mathrm{a}}$ & $130^{b}$ & $170^{b}$ & $220^{\mathrm{a}}$ & 20 & $18^{\mathrm{a}}$ & $13^{\mathrm{b}}$ & $11^{\mathrm{b}}$ & $10^{b}$ & 2 \\
\hline Total grasses & $1,150^{b}$ & $940^{c}$ & $1,190^{b}$ & $2,060^{\mathrm{a}}$ & 80 & $84^{b}$ & $94^{a}$ & $80^{c}$ & $98^{\mathrm{a}}$ & 1 \\
\hline Forbs & $210^{b}$ & $60^{\mathrm{c}}$ & $300^{\mathrm{a}}$ & $50^{\mathrm{c}}$ & 20 & $16^{\mathrm{b}}$ & $6^{\mathrm{c}}$ & $20^{a}$ & $2^{c}$ & 1 \\
\hline Total herbage & $1,360^{b}$ & $1,000^{\mathrm{c}}$ & $1,480^{b}$ & $2,110^{\mathrm{a}}$ & 90 & $\ldots$ & -.- & -.. & -.. & - \\
\hline
\end{tabular}

Means within component followed by different letters are significantly different, $\mathrm{P}<0.05$.

${ }^{2}$ Significant stocking rate by year interaction, $\mathrm{P}=0.02$.

Companion hydrological studies at our study site suggested that herbaceous production would be negatively affected by stocking rate. Rhoades et al. (1964), working in the same pastures on Eda soils, found water infiltration rates of 118,91 , and $58 \mathrm{~mm} \mathrm{hr}^{-1}$ under the stocking rates of 43, 57, and 85 AUD ha ${ }^{-1} \mathrm{y}^{-1}$, respectively. It might be expected that such differences in the rate of water infiltration into the soil would reduce average soil water content and plant production. Apparently the infiltration rate at 85 AUD ha $^{-1} \mathrm{y}^{-1}$ was not below a critical level that would impact overall water relations, even though it was only $50 \%$ of the infiltration rate under the lowest stocking rate of $43 \mathrm{AUD} \mathrm{ha}^{-1} \mathrm{y}^{-1}$.

Milchunas and Lauenroth (1993) found that the relationship between grazing intensity and above-ground net primary production (ANPP) was weak when viewed over a wide range of environments. While most studies reported negative impacts of grazing on ANPP, a significant proportion found no impact or a small positive impact. In their comparative analyses (Milohunas and Lauenroth 1993), grazing intensity had the smallest impact in grasslands with relatively low ANPP and a long evolutionary history of grazing, both of which are characteristics of our study site (Sims and Singh 1978, Sala et al. 1988).

We detected no practical changes in species composition caused by stocking rate. Burzlaff and Harris (1969) also reported no large changes in species composition due to stocking rate on sandy rangeland. However, Sims et al. (1976) observed directional changes in several species at higher stocking rates. While blue grama increased in the study of Sims et al. (1976), this species was highly variable and did not respond to stocking rate in the current study. As with total production, species composition was relatively insensitive to stocking rate in this sand sagebrush-grassland.

Herbaceous production was more responsive to weather than to stocking rate. The differences in production among years were much greater than the differences among stocking rates for all components. Little bluestem and sand lovegrass showed the greatest responses to periods of favorable precipitation. These 2 species would be most useful as indicators of precipitation trends. On the other hand, sand dropseed and blue grama were not responsive to precipitation and, as a result, their relative contribution to total production declined during a period of increased precipitation.

Milchunas et al. (1994) hypothesized that long-term heavy grazing might reduce the ability of a grassland to increase production in years of favorable precipitation. However, when testing this hypothesis in shortgrass steppe Milchunas et al. (1994) found that heavy grazing did not reduce production potential in years with high precipitation. Our results also reject this hypothesis since herbaceous production responded to favorable precipitation equally well at all stocking rates throughout the measurement period.

There is a common perception in grassland management that forbs increase as stocking rates increase. This is based on the logic that cattle prefer grasses and alter the competitive interactions between grasses and forbs at high stocking rates. Forb standing crop was not affected by stocking rate in the last 4 years of this study. During the first 10 years, basal cover of perennial forbs was lower at a stocking rate of $85 \mathrm{AUD} \mathrm{ha}^{-1} \mathrm{y}^{-1}$ than at either 43 or 57 AUD ha- $1 \mathrm{y}^{-1}$, which had similar covers of perennial forbs (Sims and Gillen 1999). Basal cover of annual forbs was not affected by stocking rate. Annuals dominated the forb community with 4 to 6 times more basal area than perennials (Sims and Gillen 1999). We hypothesize that these annual forbs were more responsive to variations in precipitation than to stocking rate. Burzlaff and Harris (1969) and Sims et al. (1976) also found that forbs did not respond to stocking rate treatments on sandy soils.

On the other hand, at this same study site, standing crop of both perennial and annual forbs was lower in areas excluded from grazing for over 50 years than in adjacent areas grazed at rates of 50 to 55 AUD ha ${ }^{-1} \mathrm{y}^{-1}$ (Berg et al. 1997). This suggests that the simple presence or absence of grazing is more important than the intensity of grazing. The response of forbs to stocking rate appears to be more complex than previously recognized and the current model that predicts linear increases in forbs as stocking rates increase should be reconsidered.

Sustainable management requires consideration of both biological and economic sustainability. The range of stocking rates in this study appears to be biologically sustainable, in terms of herbaceous production, since no large negative effects were noted after 20 years. Economic sustainability is dependent on livestock performance and there were clear differences among stocking rates for that variable (Sims and Gillen 1999, Gillen and Sims 2002). Economic returns from yearling steer grazing during the first 10 years of this study were maximized at a stocking 
rate above the range of our experimental stocking rates (Sims and Gillen 1999). Therefore, we cannot draw conclusions on the sustainability of profit-maximizing stocking rates for yearling steers. Economic returns from cow-calf production from 1954 to 1961 were maximized at 68 AUD ha $^{-1} \mathrm{y}^{-1}$ (Gillen and Sims 2002), a stocking rate that appears to be sustainable in terms of herbaceous production.

\section{Literature Cited}

Berg, W.A. 1994. Sand sagebrush-mixed prairie, p. 99. In: T.N. Shiflet (ed.) Rangeland cover types of the United States. Soc. Range Manage., Denver, Colo.

Berg, W.A., J.A. Bradford, and P.L. Sims. 1997. Long-term soil nitrogen and vegetation change on sandhill rangeland. J. Range Manage. 50:482-486.

Burzlaff, D.F. and L. Harris. 1969. Yearling steer gains and vegetation changes of western Nebraska rangeland under three rates of stocking. Nebr. Agr. Exp. Sta. SB-505. Lincoln, Nebr.

Gillen, R.L. and P.L. Sims. 2002. Stocking rate and cow-calf production on sand sagebrush rangeland. J. Range Manage. 55:542-550.
Holechek, J.L., R.D. Pieper, and C.H. Herbel. 1995. Range Management, Principles and Practices. $2^{\text {nd }}$ Ed. Prentice Hall, Englewood Cliffs, N.J.

Küchler, A.W. 1964. Potential natural vegetation of the conterminous United States. Amer. Geograph. Soc. Spec. Pub. 36, New York, N.Y.

Küchler, A.W. 1975. Potential natural vegetation of the conterminous United States [Map].Amer. Geograph. Soc., New York, N.Y.

Milchunas, D.G. and W.K. Lauenroth. 1993. Quantitative effects of grazing on vegetation and soils over a global range of environments. Ecol. Monogr. 63:327-366.

Milchunas, D.G., J.R. Forwood, and W.K. Lauenroth. 1994. Productivity of long-term grazing treatments in response to seasonal precipitation. J. Range Manage. 47:133-139.

Pechanec, J.F. and G.D. Pickford. 1937. A weight estimate method for the determination of range or pasture production. Agron. J. 29:894-904.

Rhoades, E.D., L.F. Locke, H.M. Taylor, and E.H. McIlvain, E.H. 1964. Water intake on a sandy range as affected by 20 years of differential cattle stocking rates. J. Range Manage. 17:185-190.
Sala, O.E., W.J. Parton, L.A. Joyce, and W.K. Lauenroth. 1988. Primary production of the central grassland region of the United States. Ecol. 69:40-45.

SAS Institute Inc. 1999. SAS/STAT User's Guide, Version 8. SAS Institute Inc., Cary, N.C.

Shoop, M.C. and E.H. McIlvain. 1963. The micro-unit forage inventory method. J. Range Manage. 16:172-179.

Shoop, M.C. and E.H. McIlvain. 1971. Why some cattlemen overgraze - and some don't. J. Range Manage. 24:252-257.

Sims, P.L. and R.L. Gillen. 1999. Rangeland and steer responses to grazing in the Southern Plains. J. Range Manage. 55:651-660.

Sims, P.L. and J.S. Singh. 1978. The structure and function of ten western North American grasslands: III. Net primary production, turnover and efficiencies of energy capture and water use. J. Ecol. 66:573-597.

Sims, P.L., B.E. Dahl, and A.H. Denham. 1976. Vegetation and livestock response at three grazing intensities on sandhill rangeland in eastern Colorado. Colo. Agr. Exp. Sta. Tech. Bull. 130. Ft. Collins, Colo. 